\title{
Effects of Photoperiodism and Other Factors on the Improvement of Pigeonpea Varieties
}

\author{
Arturo Riollano ${ }^{1}$ \\ INTRODUCTION
}

Day-length in Puerto Rico, which is located in latitude $18^{\circ}$, varies from 13 hours and 12 minutes on June 10 to 11 hours and 3 minutes in December. Differences of up to 2 hours in daylight have been observed in this Island to affect plant development, and flowering and yield of such crops as sugarcane, corn, soybeans, sweetpotatoes, and field beans. The probable effect of photoperiodism on certain pigeonpea varieties has been also reported by Riollano $(1)^{2}$ and Gooding (2) in recent publications. It was shown that, disregarding time of planting, certain varieties always produced a crop during the short-day months of December, January, February, and March.

Pigeonpea varieties grown in Puerto Rico may be classified arbitrarily into three main types from the standpoint of flowering habits: Early, late, and all-season. The first two types from which the commercial varieties Kaki and Saragateado have been selected, normally flower from November to February. Blooming in these two varieties is definitely affected or caused by the short days. On the other hand, there is a group of noncommercial varieties belonging to the third type that may bloom and produce a crop at any time of the year, depending mostly upon the age of the plant, rather than on the planting season. Generally, these varieties produce sparingly, suffer most from insect damage, and the quality of the pea is inferior. However, a promising variety named Amarillo has been selected by the author, which might be used for commercial plantings in the future.

This experiment was established primarily to determine the effect of photoperiodism on flower induction in the three main types of pigeonpeas, and to develop proper techniques for further studies of this kind. It was also thought that positive results in these experiments might be very useful and practical in accelerating a breeding program for crop improvement. Pigeonpeas may bloom at a height of 2 feet, or at a height of 14 feet, depending upon the time of planting. Therefore, small, medium, and large containers were included in these studies by using 10 -inch polyethylene bags, and 1-gallon and 5-gallon metal containers.

\section{MATERIALS AND METIODS}

General instructions and information by Downs et al. (3) were followed in devising this experiment. In an existing shed, a darkroom $71 / 2 \times 71 / 2 \times 17$

${ }^{1}$ Agronomist in Charge, Isabela Substation, Agricultural Experiment Station, University of Puerto Rico, Isabela, P.R.

${ }^{2}$ Italic numbers in parentheses refer to Literature Cited, p. 235. 
feet in dimensions was built with masonite boards. A $5 \times 7$-foot trailer wagon was used for moving the plants in and out of the darkroom.

On February 9, 1962, the following pigeonpea varieties were planted in 5-gallon cans, 1-gallon cans, and 10-inch polyethylene bags:

\begin{tabular}{ll}
\multicolumn{1}{c}{ Variely } & \multicolumn{1}{c}{ Type } \\
Amarillo & All season \\
Saragateado & Late \\
Kaki & Early \\
Manolo & Do.
\end{tabular}

The potting soil used for the various containers was a mixture of $31 / 2$ parts of Coto Clay soil, $31 / 2$ parts of Guayabo fine sand, and 1 part of filterpress cake. This soil mixture was fumigated with methyl bromide prior to planting the different pigeonpea varieties.

On June 4, 1962, all the pigeonpea plants from the above-named varieties were distributed equally into two groups of three to four plants each. Group A was left outside under normal conditions of daylight. Group B was placed on the trailer for exposure to 8 hours of daylight. Daily at 7:00 a.m. plants from group $B$ were taken out of the darkroom for normal light exposure until 3:00 p.m. when they were again moved into the darkroom. All plants from both groups were watered when necessary.

The three different-sized containers were distributed at random among the two treatments of light exposure and among all the varieties under study. Maximum and minimum temperatures were taken daily inside the insulated darkroom and outside of the enclosure.

\section{RESULTS}

On July 14 flower induction was observed in Amarillo plants under both reduced light of 8 hours and normal daylight of about 13 hours. However, it was observed that flowering was retarded by about 7 days in plants exposed to reduced light. On the above date none of the other plants from the remaining varieties showed signs of flower induction, either in reduced light or under normal sunlight.

Observations made August 14 indicated that Kaki and Manolo, two early varieties, had bloomed under the reduced-light exposure of 8 hours. No signs of flower induction were observed in Saragateado, a late variety subjected to the same reduced-light treatment.

Further observations made in mid-September and in October showed that Saragateado did not bloom under the reduced-light treatment. Flower induction was observed in this variety on November 25, 7 weeks earlier than normal.

Small, medium, and large containers did not affect flower induction of varieties studied under the two light treatments. Kaki and Manolo bloomed under reduced-light treatment, regardless of the size of the container. The 
same two varieties did not bloom under natural sunlight when grown in the three different-sized containers. However, Amarillo bloomed both under reduced and normal light, in all types of containers within a period of 5 months after planting.

The records of the average maximum temperature inside the insulated darkroom, as compared with the outside maximum temperatures, showed differences of less than $1^{\circ} \mathrm{F}$. The same was true of the records of average minimum temperatures taken inside and outside the darkroom.

\section{DISCUSSION AND CONCLUSIONS}

Type of variety, length of day, and size of container were the significant variables tested in this experiment, since differences in temperature recorded inside and outside the darkroom were negligible, being less than $1^{\circ} \mathrm{F}$. The size of container did not affect the blooming characteristics of any of the varieties.

The reduced-light treatment induced flower formation in the early varieties, Kaki and Manolo, at the age of 6 months, or about 4 months earlier than when the same varieties were grown under normal sunlight. This same light treatment did not appreciably affect the all-season variety Amarillo, except that it retarded blooming by about 7 days. Varieties of this type are called "Totiempo," or all-season. This variety seemed to flower at a constant age of 4 to 5 months, independent of the time of planting.

The late Saragateado was affected by the reduced-light exposure much less than the early varieties. The former flowered under reduced light late in November, or approximately 7 weeks earlier than when grown under natural conditions of sun exposure.

In conclusion, the results of this experiment show that it is possible to accelerate a breeding program with early pigeonpea varieties by the use of a darkroom for inducing earlier flower formation. With this method two generations can be obtained in early varieties within a year, as compared with a single generation obtained in the annual cycle of reproduction under normal conditions.

With late varieties like Saragateado a reduction of light exposure had a less marked effect in inducing earlier flower formation. This gain in time, about 7 weeks, might not be worthwhile in a pigeonpea-breeding program.

The all-season varieties like Amarillo can be planted at any time of the year, whether for a breeding program or for commercial purposes. They will bloom at the early age of 4 to 5 months, independently of the time of planting. It would be advisable to intensify the improvement of pigeonpea varieties primarily with the nonseasonal type of varieties and, secondarily, with the early varieties. There is no advantage so far in the use of late varieties for commercial purposes, if all-season or early varieties of good quality and comparable high yield, can be developed. 
The size of containers definitely has no effect on the blooming habits of early, late, or all-season pigeonpea varieties. However, small-sized containers like 10-inch polyethylene bags or 1-gallon tin containers, can be used successfully and economically for propagating pigeonpeas in a breeding or experimental program.

\section{SUMMARY}

Studies on the effects of photoperiodism and other factors were conducted to obtain information which might be useful in a breeding program with pigeonpeas. The information was sought for accelerating this work in a region where extremes of day-length vary by only 2 hours because of its location in latitude $18^{\circ}$. By shortening the length of day to 8 hours through the use of a darkroom, and planting during the month of February, it was possible to induce flower formation 4 months earlier in two early varieties and 7 weeks earlier in a late variety. However, this short-day treatment did not appreciably affect the time of flower induction in an all-season, or "Totiempo" variety. One-gallon tin-can containers and 10-inch polyethylene bags were found satisfactory for growing pigeonpea plants of different varieties.

\section{RESUMEN}

Se realizaron estudios sobre fotoperiodismo y otros factores con el objeto de conseguir información necesaria para acelerar un programa para el mejoramiento de variedades de gandules en Puerto Rico, en donde en cierta época del año la luz solar dura hasta 13 horas, debido a estar situado en la latitud $18^{\circ}$. Con la reducción de la luz solar a 8 horas diarias mediante el uso de un cuarto obscuro, y efectuando la siembra durante el mes de febrero, se logró inducir la florecida 4 meses más temprano en dos variedades tempranas, y 7 semanas más temprano en una variedad tardía. No obstante, la reducción en la luz solar no tuvo efecto apreciable en la variedad "Totiempo" o de toda época. Se encontró que los recipientes estañados con capacidad de un galón y las bolsas de polietileno de 10 pulgadas son adecuadas para la propagación de distintas variedades de gandules.

\section{LITERATURE CITED}

1. Riollano, A., Pérez, A., and Ramos, C., Effects of planting date, variety, and plant population on the flowering and yield of pigeonpeas (Cajan cajan L.), J. Agr. Univ. P.R., 46 (2) 127-34, 1962.

2. Gooding, H. J., Some problems of pigeonpea improvement, J. Agr. Soc. Trinidad and Tobago, Society Paper No. 883. Sept. 1960.

3. Downs, R. J., Borthwick, H. A., and Piringer, A., Light and Plants, Misc. Pub. 879, Agr. Res. Serv., USDA, 1961. 